Samuka Vol 5 No 2 : hlm 143-151

SAMUKA

Jurnal Samudra Ekonomika

https://ejurmalunsam.id/index.php/jse

\title{
FAKTOR-FAKTOR YANG MEMPENGARUHI PENGENTASAN KEMISKINAN DI SUMATERA UTARA
}

\author{
Winda Gurning ${ }^{1}$, Weni Hawariyuni ${ }^{2}, \operatorname{Irsad}^{3}$ \\ windagurning1795@gamil.com \\ 1,2,3 Fakultas Ekonomi, Universitas Sumatera Utara, Kota Medan \\ Received: September 2021; Accepted: September 2021 Published: September 2021
}

\begin{abstract}
Abstrak
Provinsi Sumatera Utara merupakan provinsi dengan jumlah kemiskinan tertinggi di Pulau Sumatera dan peringkat ke-4 se-Indonesia. Penelitian ini dilakukan untuk menganalisis faktor-faktor yang mempengaruhi pengentasan kemiskinan pada 33 kabupaten/kota di Provinsi Sumatera Utara tahun 2017-2020. Data yang digunakan dalam penelitian ini adalah data sekunder yang diperoleh dari Badan Pusat Statistika, Kanwil Ditjen PBN Sumatera Utara dan Kantor Dinas Penanaman Modal dan PPTSP Sumatera Utara. Metode analisis data yang digunakan yaitu metode regresi data panel dengan pendekatan Fixed Effect Model dianalisis menggunakan program Eviews-11. Hasil penelitian menunjukkan bahwa Produk Domestik Regional Bruto dan Investasi berpengaruh negatif dan signifikan terhadap kemiskinan di Provinsi Sumatera Utara, sedangkan anggaran pemerintah bidang pendidikan dan anggaran pemerintah bidang kesehatan tidak berpengaruh dan tidak signifikan terhadap kemiskinan di provinsi tersebut.
\end{abstract}

Kata Kunci: Pendidikan, Kesehatan, PDRB, Investasi, Kemiskinan

\begin{abstract}
North Sumatra is the province with the highest poverty rate in Sumatra and is 4th in Indonesia. This study aims to analyze the factors that influence poverty rate in 33 regencies/cities in North Sumatra from 2017 until 2020. The data used in this study is secondary data obtained from the Central Statistics Agency, North Sumatra Treasury Regional Office, and North Sumatra Investment and Licensing. The data analysis method in this research is the panel data regression with the Fixed Effect Model approach, analyzed using the Eviews-11 software. Panel data is the data combined with the time series and cross section data. The results showed that the Gross Regional Domestic Product and Investment had a negative and significant effect on the poverty rate in North Sumatra Province, while the Education and Health budget had an insignificant effect on poverty in the province.
\end{abstract}

Keywords: Government Budget for Education, Government Budget for Health, GRDP, Investment, Poverty.

\section{PENDAHULUAN}

Salah Tujuan dasar Negara Kesatuan Republik Indonesia yang tercantum dalam undangundang adalah memajukan kesejahteraan manusia secara merata di seluruh pelosok negeri. Setelah 75 tahun Indonesia bebas dari penjajahan, perekonomian Indonesia banyak mengalami perubahan tetapi masih tetap menyandang sebagai negara berkembang, hal ini ditandai dengan gambaran perekonomian Negara Indonesia masih mengalami ketertinggalan dari negara lain terlebih akibat Krisis ekonomi yang terjadi di Indonesia pada era 1998. Krisis ekonomi yang terjadi tahun 1997-1998 telah meluluhlantakkan perekonomian Indonesia. Tatanan yang telah dibangun sebelumnya rusak dengan seketika. Nilai Tukar rupiah merosot tajam, harga-harga melambung naik, investasi macet, sektor keuangan melemah, stabilisasi politik dan keamanan 
kurang terkendali serta investor memindahkan investasinya keluar Indonesia (Maipita,2014:100). Provinsi Sumatera Utara merupakan provinsi dengan jumlah penduduk miskin tertinggi di Pulau Sumatera. Berdasarkan Informasi Badan Pusat Statistika pada tahun 2020 jumlah penduduk miskin di Sumatera Utara sebanyak 1.356.720. Selain itu, gambar dibawah ini akan memaparkan bahwa jumlah penduduk miskin di Sumatera Utara merupakan peringkat ke 4 terbanyak dari 34 provinsi di Indonesia setelah Jawa Timur, Jawa Barat, Jawa Tengah (Badan Pusat Statistika, 2020).

Berdasarkan data-data tersebut bahwa pengentasan kemiskinan perlu dimaksimalkan, Karena permasalahan kemiskinan merupakan permasalahan yang kompleks dan bersifat multidimensional. Oleh karena itu, upaya pengentasan kemiskinan harus dilakukan secara terpadu dan menyeluruh, mencakup berbagai aspek kehidupan masyarakat, dan dilaksanakan secara terpadu. Masalah kemiskinan juga perlu memperhatikan tingkat kedalaman dan keparahan kemiskinan. karena menurut Smith (dalam Todaro, 2015) bahwa tidak ada masyarakat yang makmur dan bahagia, jika sebagian besar orang dalam masyarakat itu berada dalam kemiskinan dan penderitaan

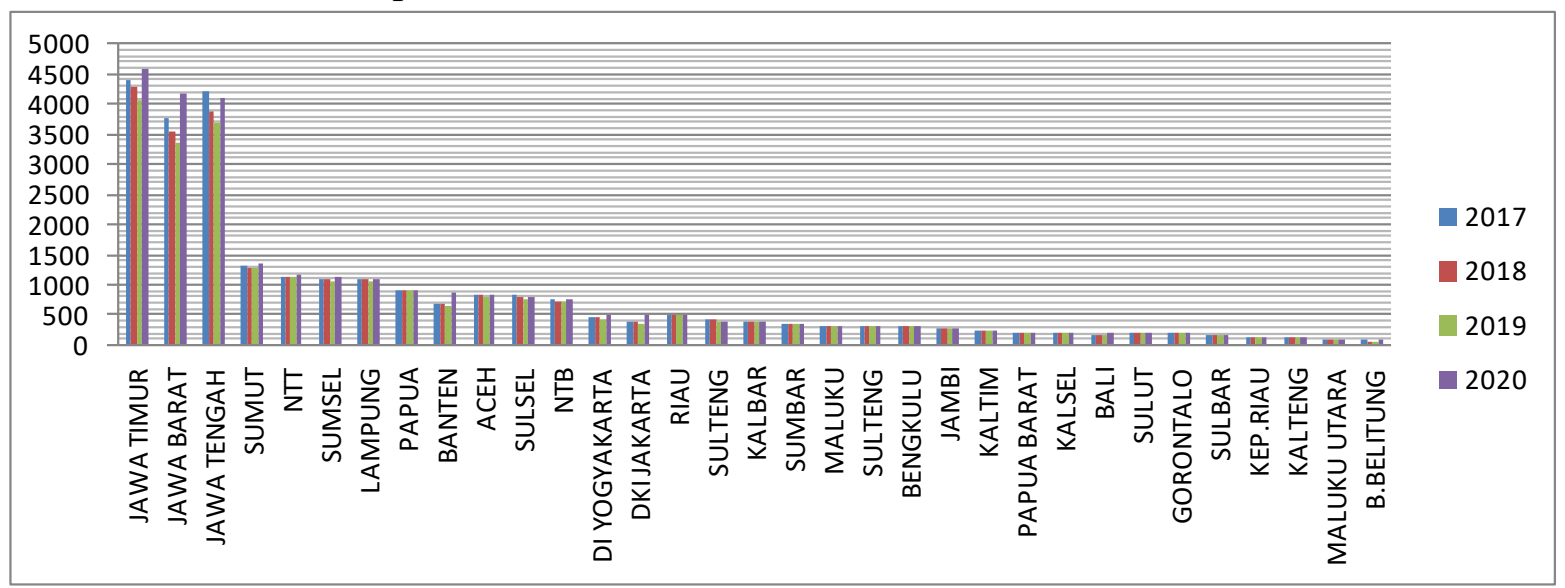

Gambar 1. Penduduk Miskin Menurut Provinsi

Sumber: BPS (2021)

Pemerintah Provinsi Sumatera Utara terus meningkatkan dan menyempurnakan berbagai program penanggulangan kemiskinan serta meningkatkan kemampuan dan pendapatan rumah tangga miskin. Menurut Todaro (2015) ada interaksi akibat kemiskinan dengan tingkat pendapatan rendah, ketimpangan pendapatan, fasilitas pelayanan kesehatan dan pendidikan kurang baik dan tidak maksimal. Memilah hal tersebut maka kemiskinan perlu dituntaskan melalui penyebab kemiskinan tersebut. Pengentasan kemiskinan dapat melalui peningkatan PDRB dan penanaman modal dan maksimalisasi peningkatan fasilitas Pendidikan dan Kesehatan.

Menurut Todaro (2015) bahwa pertumbuhan ekonomi merupakan syarat keharusan bagi pengurangan kemiskinan. sedangkan menurut Sukirno (2000) bahwa kegiatan yang memungkinkan masyarakat untuk terus meningkatkan taraf kemakmuran masyarakat dengan melakukan investasi, penanaman modal akan meningkatkan kegiatan perekonomian dan kesempatan kerja sehingga meningkatkan pendapatan nasional dan akan meningkatkan kemakmuran rakyat. Investasi akan meningkatkan stok barang/jasa, sehingga akan memberikan dampak positif bagi perekonomian, sebab peningkatan stok barang/jasa secara nasional akan meningkatkan kegiatan produksi dan juga dapat memperluas kesempatan kerja. 
Sudut pandang lain pengentasan kemiskinan juga dapat melalui pembangunan manusia. Pembangunan manusia sangat erat dengan Pendidikan dan Kesehatan. Dengan kesehatan dan pendidikan yang lebih baik produktivitas dan pendapatan yang lebih tinggi akan lebih mudah dicapai (Todaro \& Smith, 2009). Pendidikan merupakan salah satu faktor pendukung yang sangat penting bagi suatu perkembangan dan pembangunan suatu negara. Negara dikatakan maju dalam segala hal baik bidang ekonomi, teknologi, pertanian ataupun yang lainnya tidak terlepas dari peran pendidikan. Hal ini dikarenakan orang yang berpendidikan akan memberikan kontribusi yang positif terhadap negara. Orang yang terdidik akan memberikan manfaat bagi orang-orang disekitarnya seperti membagi informasi maupun melakukan inovasi. Kesehatan yang lebih baik juga akan memberikan dampak yang baik dalam masa saat seseorang bekerja maupun masa sekolah. Pengertian luas investasi pada modal manusia berarti pengeluaran dibidang pelayanan Kesehatan, Pendidikan dan sosial (Jhingan, 2012). Salah satu target dari pencapaian Millenium Development Goal (MDG) menetapkan salah satu targetnya adalah pengentasan kemiskinan yang diberlakukan untuk seluruh dunia. Adapun tujuan dari penelitian ini menganalisis Faktor-Faktor yang mempengaruhi pengentasan kemiskinan di Sumatera Utara tahun 2017-2020.

\section{Landasan Teori}

Kemiskinan adalah situasi ketidakmampuan atau nyaris tidak mampu untuk memenuhi kebutuhan dasar berupa makanan, pakaian dan tempat tinggal (Todaro, 2015). Kemiskinan adalah cross sectors problem, cross areas dan cross generation, sehingga untuk menanganinya dibutuhkan pendekatan yang terpadu, komprehensif dan berkelanjutan. Untuk mensukseskan program-program percepatan penanggulangan kemiskinan dibutuhkan political will menurut Rejekiningsih (dalam Wulandari, 2016). Menurut peraturan presiden Nomor 13 Tahun 2009 tentang koordinasi penanggulangan kemiskinan, pemahaman mengenai "kemiskinan" sudah seharusnya beranjak dari pendekatan berbasis hak (right based approach). Pendekatan right based approach mengandung arti bahwa negara berkewajiban untuk menghormati, melindungi, dan memenuhi hak-hak dasar masyarakat miskin secara bertahap.

\section{Pendidikan}

Pendidikan merupakan kebutuhan manusia yang wajib untuk dipenuhi. Sumber Daya Manusia yang dibekali Pendidikan yang baik akan memiliki kualitas untuk meningkatkan produktivitas. Untuk itu pemerintah menyediakan anggaran 20 persen dari Anggaran Pengeluaran Belanja Negara yang tercantum dalam undang-undang No.20 Tahun 2003.

\section{Kesehatan}

Kesehatan merupakan sebuah kebutuhan pokok manusia, jika tidak dipenuhi dengan baik akan menghambat aktivitas. Kesehatan yang buruk akan berdampak pada produktivitas orang dewasa maupun anak-anak. sesuai menurut Todaro (2015) bahwa kesehatan dan nutrisi mempengaruhi lapangan pekerjaan, produktivitas, upah dimana akan sangat berpengaruh secara substansial di kalangan orang miskin. Pemerintah memainkan peran sangat krusial dalam sistem kesehatan karena setidaknya ada empat alasan penting. Pertama, kesehatan sangat penting dalam mengentaskan kemiskinan karena orang-orang miskin sering sekali tidak mendapat pelayanan kesehatan dan informasi kesehatan karena miskin. Kedua, rumah tangga miskin akan mengeluarkan dana untuk kesehatan sangat sedikit karena kurang peduli terhadap eksternalisasi dari kesehatan itu sendiri, ketiga, investasi tentang kesehatan terlalu sedikit di 
negara berkembang, keempat,program-program kesehatan di negara maju sudah banyak yang berhasil.

\section{Produk Domestik Regional Bruto}

Menurut Mankiw (2007), Produk Domestik Bruto (PDB) adalah nilai pasar semua barang dan jasa akhir yang diproduksi dalam perekonomian selama kurun waktu tertentu.

\section{Investasi}

Investasi usaha mencakup pembelian barang kapital saat ini atas dasar ekspektasi adanya penerimaan di masa mendatang (Triandaru, 2000).

\section{METODE PENELITIAN}

Penelitian ini merupakan penelitian kuantitatif asosiasif. Data yang digunakan dalam penelitian ini merupakan data sekunder dimana bersumber dari Badan Pusat Statistika meliputi data kemiskinan (Y) dan Produk Domestik Regional Bruto (X3), Kantor Wilayah Perbendaharaan Sumatera Utara meliputi data anggaran pengeluaran pemerintah bidang pendidikan (X1) dan Kesehatan (X2), dan Dinas Penanaman Modal dan PTSP Provinsi Sumatera Utara meliputi investasi (X4). Adapun fokus penelitian pada 33 Kabupaten/Kota yang ada di Provinsi Sumatera Utara. Periode data tahun 2017-2020. Analisis data dalam penelitian ini menggunakan regresi data panel sebagai instrumen olah data. Data Panel adalah gabungan dari data time series dan data cross section. Dalam metode estimasi model regresi data panel dapat dilakukan melalui tiga metode, yaitu antara lain metode Pooled Least Square (PLS), Fixed Effect Model (FEM), atau Random Effect Model (REM). Berikut merupakan model analisis statistika dalam penelitian ini:

$$
\mathrm{Y}=\boldsymbol{\beta 0}+\beta 1 \mathrm{X} 1+\beta 2 \mathrm{X} 2+\beta 3 \mathrm{X} 3+\beta 4 \mathrm{X} 4+\varepsilon
$$

Dimana

$$
\begin{aligned}
& \mathrm{Y}=\text { Kemiskinan } \\
& \beta 0=\text { intersep } \\
& \beta 1, \beta 2, \beta 3, \beta 4=\text { Koefisien regresi parsial } \\
& \mathrm{X} 1=\text { Anggaran Bidang Pendidikan } \\
& \mathrm{X} 2=\text { Anggaran Bidang Kesehatan } \\
& \mathrm{X} 3=\text { PDRB } \\
& \mathrm{X} 4 \quad=\text { Investasi }
\end{aligned}
$$

\section{HASIL ANALISIS}

\section{Pemilihan Metode Penelitian.}

1. Uji chow

Pengambilan keputusan melihat nilai probabilitas (p) untuk Cross-Section F. Dari hasil analisis Nilai $\mathrm{P}<0.05$ maka model yang dipilih adalah Fixed Effect Model (FEM).

Tabel 1. Hasil Uji Chow

\begin{tabular}{lrrr}
\hline Effect Test & Statistic & d.f & \multicolumn{2}{c}{ Prob } \\
\hline Cross-Section F & 187.887809 & $(32,95)$ & 0.0000 \\
Cross- Section Chi- Square & 549.566313 & 32 & 0.0000 \\
\hline
\end{tabular}

Sumber: Data diolah Eviews 11

\section{Uji hausman}


Pengambilan keputusan dengan melihat nilai Probabilitas (p) untuk Cross-Section random. Hasil pengujian nilai $\mathrm{p}<0.05$ maka model yang dipilih adalah Fixed Effect Model. Nilai ChiSquare pada Cross-section Random $=$ dengan nilai $\mathrm{p}=0,000<0,05$, sehingga model dengan metode Fixed Effect Model.

Tabel 2. Hasil Uji Hausman

\begin{tabular}{lcrr}
\hline Test Summary & Chi- Sq. Statistic & Chi-Sg. D.f. & \multicolumn{2}{l}{ Prob. } \\
\hline Cross-section random & 124.934166 & 4 & 0.0000 \\
\hline
\end{tabular}

Sumber Data diolah software 11

Setelah melakukan pengujian dengan Uji chow dan Uji Hausman maka ditemukan model terbaik dengan Fixed Effect Model (FEM).

\section{Uji Statistik}

Berdasarkan hasil regresi data panel dengan menggunakan metode Fixed Effect Model diperoleh nilai koefisien regresi untuk setiap variabel dalam penelitian dengan persamaan sebagai berikut :

Tabel 3. Hasil Fixed Effect Model

\begin{tabular}{lcccc}
\hline \multicolumn{1}{c}{ Variable } & Coefficient & Std. Error & t-Statistic & Prob. \\
\hline C & 492.0371 & 36.23516 & 13.57900 & 0.0000 \\
LogPendidikan & -0.345846 & 0.258302 & -1.338921 & 0.1838 \\
LogKesehatan & 0.387104 & 0.263941 & 1.466627 & 0.1458 \\
LogPDRB & -16.18916 & 1.241396 & -13.04109 & 0.0000 \\
LogInvestasi & -0.018611 & 0.008528 & -2.182223 & 0.0316 \\
\hline R-squared & & & & 0.9922 \\
Adjusted R-squared & & & & 0.9892 \\
F-statistic & & & & 331,47 \\
Prob(F-statistic) & & & & 0,0000 \\
\hline
\end{tabular}

Sumber: data diolah dengan eviews 11

\section{Determinan Koefisien}

Masing-masing Variabel dependent dan variabel independen yang diikutsertakan dalam model estimasi pada tabel 3 di atas diperoleh koefisien determinasi $\left(\mathrm{R}^{2}\right)$ terletak antara 0 sampai 1. Masing-masing Variabel dependen dan variabel independen yang disertakan dalam model estimasi pada gambar 3 di atas diperoleh koefisien determinasi $\left(\mathrm{R}^{2}\right)$ sebesar $0,992 \%$ berarti secara keseluruhan variabel yaitu anggaran pemerintah bidang pendidikan, anggaran pemerintah bidang kesehatan, Produk Domestik Regional Bruto dan investasi mampu menjelaskan variasi kemiskinan di Sumatera Utara sebesar 99,2\% selama kurun waktu 4 tahun yaitu 2017-2020.

\section{Uji f (Simultan)}

Berdasarkan hasil regresi diperoleh nilai F-hitung= $336.9117>$ F-Tabel $=2$,44, dengan $p$ value $(0,000)>$ dari 0,005 maka keputusannya adalah Ho ditolak dan H1 diterima. Sehingga Uji F menyatakan bahwa Variabel Independen yaitu anggaran pemerintah bidang pendidikan, anggaran pemerintah bidang kesehatan, PDRB, dan Investasi secara bersama-sama berpengaruh dan signifikan terhadap variabel dependen yaitu tingkat kemiskinan di 33 Kabupaten/Kota Provinsi Sumatera Utara Tahun 2017-2020. 


\section{Uji t (Parsial)}

Berdasarkan uji t-statistik dapat diketahui bahwa PDRB dan Investasi berpengaruh negatif signifikan terhadap kemiskinan menurut kabupaten /kota Sumatera Utara. Anggaran pendidikan dan Kesehatan tidak berpengaruh dan tidak signifikanterhadap kemiskinan di 33 Kabupaten/Kota Provinsi Sumatera Utara. Berikut pemaparan hasil uji parsial untuk masingmasing variabel.

Berdasarkan dari koefisien anggaran pemerintah bidang pendidikan adalah --0.345846 sementara t-hitungnya adalah -1.338921 sedangkan probabilitas yang dihasilkan adalah 0,1838 lebih besar dari $5 \%(\mathrm{p}>\alpha)$ sehingga secara statistik maka variabel anggaran pemerintah bidang pendidikan tidak berpengaruh dan tidak signifikan terhadap kemiskinan di Sumatera Utara tahun 2017-2020. (Ho diterima dan H1 ditolak).

Berdasarkan dari koefisien anggaran pemerintah bidang kesehatan adalah $\quad 0.387104$ sementara t-hitungnya adalah 1.466627 sedangkan probabilitas yang dihasilkan adalah 0,1458 lebih besar dari $5 \%(p>\alpha)$ sehingga secara statistik maka variabel anggaran pemerintah bidang kesehatan tidak berpengaruh dan tidak signifikan terhadap kemiskinan di Sumatera Utara tahun 2017-2020. (Ho diterima dan H1 ditolak).

Berdasarkan dari koefisien Produk Domestik Regional Bruto adalah -16.18911 sementara t-hitungnya adalah -13.04108 >1,6566 sedangkan probabilitas yang dihasilkan adalah 0,0000 lebih kecil dari 5\% $(\mathrm{p}<\alpha)$ sehingga secara statistik variabel Produk Domestik Regional Bruto berpengaruh negatif dan signifikan terhadap kemiskinan di 33 Kabupaten/Kota Provinsi Sumatera Utara. Hal ini berarti bahwa semakin meningkat Produk Domestik Regional Bruto maka kemiskinan semakin turun. Koefisien regresi Produk Domestik Regional Bruto sebesar -16.18916 berarti setiap peningkatan Produk Domestik Regional Bruto sebesar 1\% akan menyebabkan tingkat kemiskinan turun sebesar $-16.18916 \%$ dilihat dari nilai koefisien regresi yang lebih besar dari satu, maka variabel Produk Domestik Regional Bruto bersifat elastis terhadap kemiskinan. (Ho ditolak dan menerima H1)

Berdasarkan dari koefisien Investasi adalah -0.018611 sementara t-hitungnya adalah $2.182223>1.6566$ sedangkan probabilitas yang dihasilkan adalah 0.0354 lebih kecil dari 5\% $(\mathrm{p}<\alpha)$ sehingga secara statistik variabel Investasi berpengaruh negatif dan signifikan terhadap kemiskinan di 33 Kabupaten/Kota Provinsi Sumatera Utara. Hal ini berarti bahwa semakin meningkat Investasi maka kemiskinan semakin turun. Koefisien regresi Investasi sebesar 0,018611 berarti setiap peningkatan anggaran bidang kesehatan sebesar 1\% maka akan menyebabkan tingkat kemiskinan turun sebesar $0.018611 \%$ dilihat dari nilai koefisien regresi yang lebih besar dari satu, maka investasi bersifat inelastis terhadap kemiskinan.

\section{Pembahasan}

Perkembangan kemiskinan di 33 Kabupaten/kota di Provinsi Sumatera Utara cukup bervariasi, hal ini disebabkan oleh banyak faktor seperti perbedaan kesempatan kerja yang tersedia di wilayah, Infrastruktur, kebijakan wilayah, dan lain sebagainya. kota dengan tingkat kemiskinan tertinggi yaitu kota Medan yakni 183.540 jiwa dan kota dengan jumlah penduduk miskin terendah adalah Kota Sibolga yaitu 10.490 jiwa. Sedangkan untuk tingkat Kabupaten langkat merupakan tingkat kabupaten dengan jumlah penduduk miskin tertinggi yaitu 101.870. Kabupaten dan Kabupaten Pakpak Bharat dengan jumlah penduduk miskin terendah yaitu 4.950 jiwa. 
Sesuai hasil estimasi data variabel pengeluaran pemerintah bidang pendiidkan tidak berpengaruh dan tidak signifikan. Fenomena ini dapat disebabkan karena pertama, penduduk miskin masih kesulitan untuk melanjut sekolah ke jenjang yang lebih tinggi setelah lulus Sekolah Menengah sederajat dimana mayoritas disebabkan oleh biaya, sedangkan untuk bekerja di bidang tertentu untuk memperoleh pekerjaan dan pendapatan yang tinggi sering sekali diwajibkan harus lulusan perguruan tinggi. Kedua, Kurangnya lapangan kerja, dimana banyak lulusan sarjana muda yang memilih menganggur karena pekerjaan yang tersedia tidak sesuai bidang atau penghasilan tidak sesuai dengan yang diharapkan. Ketiga, ada lulusan sarjana muda lebih memilih menerima gaji kecil ketimbang menganggur dimana diperlihatkan masih banyaknya perusahaan dengan memberi gaji pokok dibawah UMR yang sudah ditentukan. Dari hasil penelitian disimpulkan bahwa variabel anggaran pemerintah bidang Pendidikan belum tepat sasaran dalam menurunkan tingkat kemiskinan di 33 Kabupaten/Kota Provinsi Sumatera Utara.

Hasil Estimasi data menunjukkan variabel anggaran bidang kesehatan tidak berpengaruh dan tidak signifikan. Fenomena ini dijelaskan anggaran kesehatan yang dikeluarkan oleh pemerintah cenderung dialokasikan untuk pembangunan fisik seperti pembangunan rumah sakit dan peningkatan sarana-prasarana rumah sakit pemerintah, akan tetapi sarana dan prasarana itu dimanfaatkan kurang maksimal oleh orang miskin dipengaruhi oleh ketidakmampuan materi dalam memenuhi kebutuhan akan kesehatan. Hasil penelitian disimpulkan bahwa variabel anggaran kesehatan belum tepat sasaran dan menurunkan tingkat kemiskinan di 33 Kabupaten/Kota Provinsi Sumatera Utara.

Hasil estimasi data menunjukkan variabel Produk Domestik Regional Bruto berpengaruh negatif signifikan terhadap kemiskinan. Sesuai dengan teori Todaro (2015) bahwa salah satu syarat untuk mengurangi kemiskinan melalui pertumbuhan ekonomi. Selain itu, syarat kecukupan bahwa pertumbuhan ekonomi efektif dalam mengurangi kemiskinan. Artinya, sudah seharusnya pertumbuhan ekonomi menyebar di seluruh kalangan tanpa memandang miskin atau kaya. Apabila pertumbuhan ekonomi mengalami kenaikan maka akan meningkatkan pendapatan masyarakat. Apabila pendapatan masyarakat terus bertambah maka dapat diperkirakan masyarakat akan terbebas dari kemiskinan. Sehingga ketika pertumbuhan ekonomi naik maka kemiskinan turun. Sesuai dengan penjelasan diatas bahwa peningkatan nilai PDRB di 33 Kabupaten/ Kota Provinsi Sumatera Utara pada tahun 2017-2020 mampu mengurangi kemiskinan di Wilayah tersebut karena nilai PDRB yang semakin tinggi tiap tahunnya dan menyebar ke seluruh golongan.

Hasil estimasi data menunjukkan variabel investasi berpengaruh negatif signifikan terhadap kemiskinan di 33 Kabupaten/ Kota Provinsi Sumatera Utara. Sesuai dengan pendapat Sukirno (2000) bahwa investasi merupakan salah satu cara yang memungkinkan untuk meningkatkan kemakmuran masyarakat. Penanaman modal akan meningkatkan kegiatan perekonomian dan kesempatan kerja sehingga meningkatkan pendapatan nasional dan akan meningkatkan kemakmuran rakyat.

Salah satu target dari pencapaian Millenium Development Goal (MDG) menetapkan salah satu targetnya adalah pengentasan kemiskinan yang diberlakukan untuk seluruh dunia. Dimana menurut Mudrajad (2006) mengarahkan pada teori lingkaran setan kemiskinan. keterbelakangan, ketidaksempurnaan pasar, dan kurangnya modal menyebabkan rendahnya produktivitas. Produktivitas yang rendah akan menyebabkan rendahnya pendapatan yang 
diterima. Rendahnya pendapatan akan menyebabkan rendahnya tabungan, dan tabungan akan menyebabkan rendahnya investasi. Investasi yang rendah akan mengurangi pembukaan lapangan pekerjaan, ketidaksediaan lapangan pekerjaan akan menyebabkan minimnya peluang untuk meningkatkan pendapatan masyarakat, ketika pendapatan masyarakat rendah maka mengakibatkan ketidakmampuan memenuhi kebutuhan hidup secara baik, ketika kebutuhan hidup tidak terpenuhi maka akan mengakibatkan ketidaksejahteraan. Maka dari itu semua untuk bisa keluar dari lingkaran kemiskinan dibutuhkan kerja sama dari semua pihak baik pemerintah, masyarakat luas, kaum kapitalis, dan politikus, yang dimulai dari diri sendiri untuk melakukan yang terbaik.

\section{KESIMPULAN}

Hasil penelitian menunjukkan bahwa Produk Regional Bruto dan Investasi berpengaruh negatif dan signifikan terhadap kemiskinan di Provinsi Sumatera Utara, sedangkan anggaran pemerintah bidang pendidikan dan Kesehatan tidak berpengaruh dan tidak signifikan di Provinsi Sumatera Utara Tahun 2017-2020.

Anggaran pengeluaran pemerintah bidang Pendidikan maupun anggaran pemerintah bidang Kesehatan perlu dimonitoring dan dievaluasi secara berkala supaya setiap kebijakan yang ditetapkan lebih tepat sasaran.

\section{REFERENSI}

Agustina, E. Rochaida, E. \& Ulfah, U. 2016. Pengaruh Pengeluaran Pemerintah Daerah Sektor Pendidikan dan Kesehatan Terhadap Produk Domestik Regional Bruto Serta Indeks Pembangunan Manusia di Kalimantan Timur. Jurnal Ekonomi dan Management. Volume 2:192-217.

Amalia, R. Madrid. \& Razak, R. A. 2015. Pengaruh Pengeluaran Pemerintah Terhadap Kemiskinan di Provinsi Sulawesi Barat. Jurnal Analisis.Volume 2:183-189.

Ariwani, M. A. D \& Kartika, I. N. 2019. Pengaruh PDB dan Pengeluaran Pemerintah Terhadap IPM dan Tingkat Kemiskinan di Kabupaten /Kota Provinsi Bali. E-Jurnal EP Unud.Volume 8:2927-2958.

Asghar, N., Hussain, Z., \& Rehman, H. 2012. The Impact of Government Spending on Poverty Reduction: Evidence From Pakistan 1972 to 2008. African Journal of Business Management. Volume 6: 845-853.

Badrudin, Rudy. 2012. Ekonomi Otonomi Daerah.UPP Stim YKPN: Yogyakarta.

Effendi, N. \& Setiawan, M. 2015. Ekonometrika: Pendekatan Teori dan Terapan. Salemba Empat: Jakarta.

Gupta, S., Verhoeven, M., \& Tiongson, E. The Effectiveness of Government Spending on education and HealthCare in Developing and Transition Economies. European Journal of Political Economy. Volume 18:717-737.

Hasyim, Ibrahim. 2017. Ekonomi Makro. Kencana: Depok.

Hatta, T. 2018. Pengaruh Pengeluaran Pemerintah pada Bidang Pendidikan dan Bidang Kesehatan Terhadap Kemiskinan di Wilayah Ajappareng. Jurnal Ekonomi dan Bisnis. Volume 3:39-49.

Kahang, M. Saleh, M. \& Suharto, R. B. 2016. Pengaruh Pengeluaran Pemerintah Sektor Pendidikan dan Kesehatan Terhadap Indeks Pembangunan Manusia Di Kabupaten Kutai Timur. Jurnal Ekonomi. Volume 2:1411-1713.

Lubis, P. \& Zulham, Salman. 2016. Analisis Faktor-Faktor yang mempengaruhi permintaan investasi di Indonesia. Jurnal Perpektif Ekonomi Darusalam. Volume 2,147-166. 
Mankiw. G. 2007. Pengantar ekonomi: Edisi Kedua. Haris Munanda, Penerjemah. Wisnu Kristiaji, Editor. Erlangga, Jakarta. Terjemahan dari: Harcourt.Inc.

Muliza, M. Zulham, T. \& Seftarita, C. 2017. Analisis Pengaruh Belanja Pendidikan, Belanja Kesehatan, Tingkat Kemiskinan dan PDRB Terhadap IPM di Provinsi Aceh. Jurnal Perspektif Ekonomi. Volume 3:2502-6976.

Journal of Human-Social Science: E Economics. Volume 14: 1-8.

Pangestika, Styfanda. 2015. Analisis Estimasi Model Regresi Data Panel dengan Pendekatan Common Effect Model (CEM), Fixed Effect Model (FEM), dan Random Effect Model (REM). Skripsi. Semarang: Universitas Negeri Semarang.

Putra, Windu. 2018. Perekonomian Indonesia: Penerapan beberapa teori ekonomi pembangunan di Indonesia.Rajagrafindo Persada: Depok.

Rachbini, W., Sumarto, A., Rachbini, D. 2018. Statistika Terapan. Mitra Wacana Media: Jakarta.

Rahayu, A.S. 2014. Pengantar Kebijakan Fiskal.Bumi Aksara: Jakarta.

Sari, N, I. 2018. Determinan Tingkat Kemiskinan di Daerah Istimewa Yogyakarta Tahun 20072014. Economy Development Analysis Journal.Volume 2:128-136.

Sarwono, J. \& Hendra. 2014. Eviews: Cara Operasi dan Prosedur Analisis. Andi Offset: Jakarta.

Silalahi, U. 2018. Metodologi Analisis Data dan Interpretasi Hasil: Penelitian Sosial Kuantitatif. PT Refika Aditama: Bandung..

Solikin, Akhmad. 2018. Pengeluaran Pemerintah dan Perkembangan Perekonomian (Hukum Wagner) di Negara Sedang Berkembang: Tinjauan Sistematis. Jurnal Info Artha.Volume 2: 65-89.

Sukirno. S. 2014. Makroekonomi: Teori Pengantar. Rajagrafindo Persada: Jakarta

Sugiyono. 2007. Metode Penelitian Pendidikan, Pendekatan Kuantitatif, Kualitatif, dan R\&D. Alfabeta: Bandung.

Tambunan, T. 2018. Perekonomian Indonesia. Penerbit Ghalia Indonesia: Bogor.

Todaro. Michael. 2015. Pembangunan Ekonomi di Dunia Ketiga. Munandar, Penerjemah. Sumiarti, Editor. Erlangga, Jakarta.

Wulandari, N, R. 2016. Faktor-Faktor yang mempengaruhi Rumah Tangga di Kota Kendari Tahun 2014. Jurnal Progres Ekonomi Pembangunan. Volume 1: 111-119. 